\title{
How to impact gluten protein network formation during wheat flour dough making
}

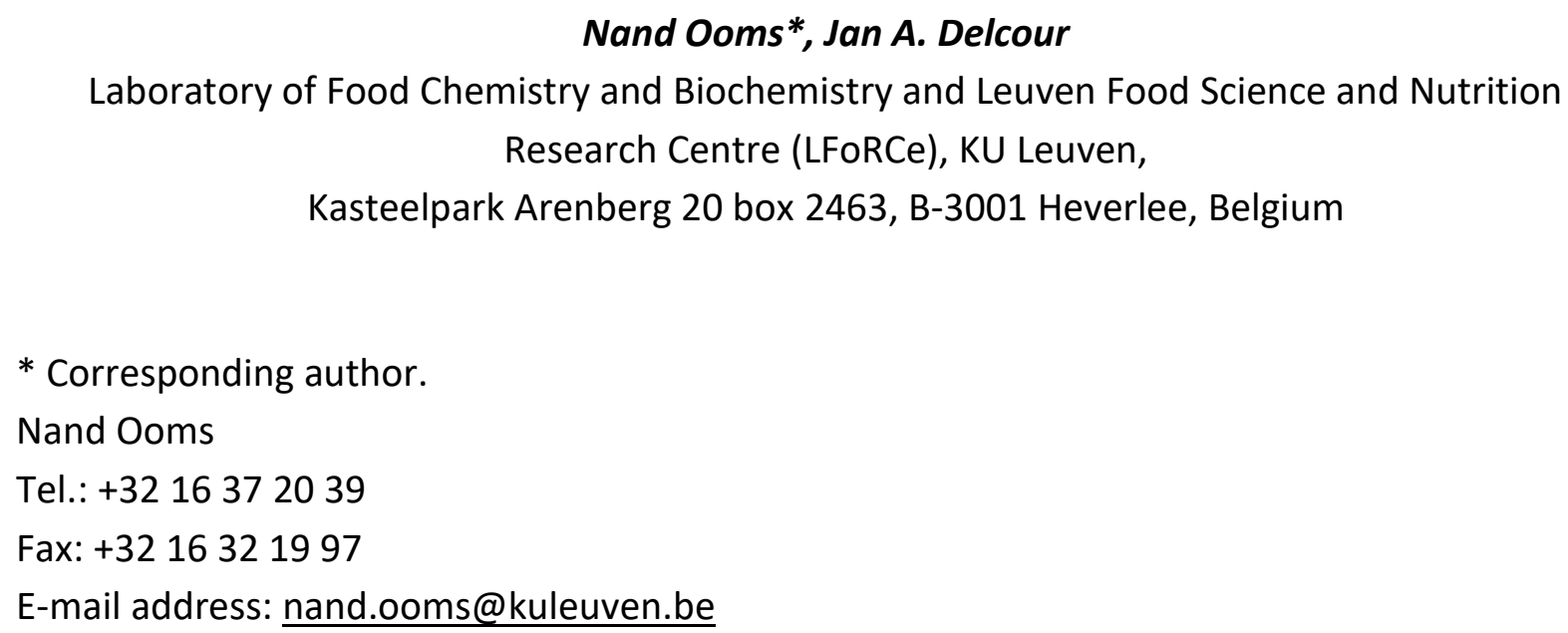

\section{KEYWORDS}

Gluten protein network, glutenin, gliadin, redox agents, enzymes, processing 


\section{INTRODUCTION}

Wheat is grown on more land area than any other food crop and is the second most-produced cereal after maize (FAOSTAT, 2016). The visco-elastic dough making capability of its flour resides primarily in gluten, wheat's main storage protein [1]. Since the discovery of wheat gluten was reported by Beccari in 1728 [2], research on its structure, functionality and how to control these aspects has been ongoing.

\section{THE GLUTEN NETWORK}

Gluten makes up $80-85 \%$ of the total wheat flour protein [3] and consists of monomeric gliadins and polymeric glutenin proteins [4]. Gluten characterization is difficult, as the term 'gluten' groups a complex mixture of homologous proteins that vary widely in molecular mass and charge [2]. Nevertheless, many researchers have taken on this challenging task, thereby applying an summarized and reviewed elsewhere $[1,2,4,9-11]$.

42 Gluten proteins determine the visco-elastic properties of wheat flour dough [4] as they are able to form a network upon hydrating and mixing wheat flour [12]. Gluten proteins consist of polymeric glutenin proteins and monomeric gliadins. Differences in the structures of glutenin and gliadin proteins provide them with different functionalities during dough formation. It is generally accepted that glutenin proteins build up the polymeric protein network that provides cohesiveness and elasticity to dough [13], whereas gliadins act as plasticizers of the glutenin network and contribute to dough viscosity and extensibility [1].

Gliadin proteins are a heterogeneous mixture of proteins with molecular masses of 30 to $75 \mathrm{kDa}$ $[3,10]$. They are subdivided into $\alpha$-, $\gamma$-and $\omega$-gliadins. The $\alpha$-and $\gamma$-gliadins contain cysteine residues, which are all involved in intramolecular disulfide (SS) bonds at ambient conditions [1]. $\omega$-Gliadin lacks cysteine residues [3]. Gliadin's primary structure consists of a short N-terminal domain, a central repetitive domain containing mainly glutamine, proline and hydrophobic amino acids and a non-repetitive C-terminal domain, which contains most of the cysteine residues, if present [1]. The secondary structure of gliadins consists of predominantly $\beta$-turns in the $\mathrm{N}$ terminal domain and $\alpha$-helix and $\beta$-sheet structures in the C-terminal domain [4]. All gliadins are 
assumed to in their native state be globular monomers [2]. Glutenins are the largest polymers found in nature. They have molecular masses ranging up to several tens of millions kDa. They consist of glutenin subunits (GS) linked together by intermolecular SS bonds [10]. In addition, GS also contain intramolecular SS bonds $[1,3,4]$. Typically, a distinction is made between high molecular mass (HMM-GS) and low molecular mass (LMM-GS) GS. As is the case for gliadin, the primary structure of GS consists of an N-terminal and C-terminal non-repetitive domain enclosing a repetitive central domain [13]. The hydrophilic central domain is rich in glutamine [10], whereas the hydrophobic $\mathrm{N}$-and $\mathrm{C}$-terminal domains contain most of the cysteine residues [1]. While the secondary structure of HMM-GS shows a predominance of aperiodic and $\alpha$-helix conformations in both the $\mathrm{N}$ - and C-terminal domains [124], the central area shows a $\beta$-spiral structure [2]. Although relatively little is known about the structures of LMM-GS, the N-terminal domain is thought to contain mainly $\beta$-turns, whereas a-helices are predominant in the C-terminal domain [125].

Different types of reactions and interactions are crucial for the formation of a gluten network upon dough mixing. Intermolecular disulfide (SS) bonds between glutenin polymers are key in this respect. The oxidation of free thiol (SH) groups to SS bonds, which increases the molecular weight of the glutenin aggregates, as well as SH-SS exchange reactions are of utmost importance for building a three dimensional gluten network during mixing [4, 14]. SH-SS exchange reactions are initiated either by low molecular weight SH compounds or by free SH groups in glutenin proteins [15]. Other covalent bonds have also been suggested to be important for gluten network formation. Morel et al. (2002) found indications for the formation of isopeptide bonds during mixing. Nevertheless, they reasoned that their contribution to gluten network formation would be negligible [16]. Tiley et al. (2001) claim that dityrosine linkages are also formed during dough making. According to Hanft and Koehler (2005), it is unlikely for dityrosine to play an important role in in wheat gluten structure, since only very a low amount of dityrosine is present in dough. Peña et al. (2006) confirm that the amount of crosslinking between tyrosine residues appears to be small during bread making and of little importance compared to disulfide bond formation. The importance of non-covalent interactions has been established. The high levels of glutamine in gluten proteins allow for intermolecular as well as intramolecular hydrogen bonds [10]. Although 
they are much weaker than covalent bonds, their large number and their ability to interchange under stress renders them main determinants of the gluten network's properties [122]. Indeed, the dough weakening effect of hydrogen bond breaking agents such as urea and the dough strengthening effect of heavy water when compared with that of ordinary water illustrates the importance of hydrogen bonds in the structure of the gluten network [4]. According to Sapirstein and Fu (2000) [123], as cited in [122], gliadin and glutenin from different flour samples differ in the number of interacting hydrogen bonds. Therefore, the specific surface area of glutenin determines the rate of interactions and, thus, the mixing time required for full dough development [123]. Hydrophobic bonds also contribute to gluten network structure [19]. They result from interactions of non-polar groups in the presence of water. Their functionality in the gluten network is likely similar to that of hydrogen bonds, although their overall contribution is thought to be smaller, as evidenced by the rheological effects of adding organic solvents to dough systems [122]. Finally, although gluten proteins have a low charge density due to the relatively low level of basic amino acids and the presence of the amide form of acidic amino acids [2], the importance of ionic interactions has nevertheless been established [20].

Over the years, several models have been proposed to describe the gluten network's structure, often focusing on explaining dough visco-elastic properties [3-9]. For an extensive overview of these models, the interested reader is referred to the review papers by Bock and Seetharaman (2012) [2]• and Ortolan and Steel (2017) [124]•. One of the models commonly accepted is the so-called 'loop-train model' proposed by Belton (1999) [47]. In this model, the HMM-GS are represented by long chains that are comprised of zones dominated by polymer-polymer interactions (i.e. 'trains') and zones dominated by polymer-solvent interactions (i.e. 'loops'), both of which are mainly hydrogen bonds. Hydration of the gluten network results in the formation of more hydrated loop regions. Belton associates the train regions with the formation of $\beta$-sheets and the formation of the loops with hydrated $\beta$-turn structures. Stretching of the gluten network would result (i) in deformation of the loop regions and (ii) in the trains being pulled apart. The elongation of the chains results in a loss of entropy. When the extension is removed and the polymers relax, the structure returns to the equilibrium of loops and trains. 


\section{IMPACTING GLUTEN NETWORK FORMATION}

Multiple approaches have been taken to alter gluten network structure and, thus, functionality during wheat flour dough making. Gluten protein functionality strongly depends on the specific dough recipe, as water and other typical dough components such as salt significantly impact gluten network formation. The different mechanical unit operations during dough making such as mixing and sheeting determine the degree of gluten development. Furthermore, a range of improving agents are commonly used in the baking industry. They allow better control of production processes, improve product quality and/or increase shelf-life. Redox agents and enzymes are much used for altering gluten network formation.

In what follows, we briefly outline all strategies above. Where appropriate, the reader is referred to more in-depth review papers on specific approaches.

\subsubsection{Influence of processing steps}

\section{Flour treatments}

Oxidizing agents can be added to flour in order to accelerate its natural maturation, i.e. 'flour bleaching'. One of the most commonly used oxidizing agents for bleaching is benzoyl peroxide [21]. This component is assumed to exhibit its decolorizing action without influencing flour baking properties [22]. Other peroxides, such as acetone peroxide, are also used [23]. Where allowed, chlorine gas can also be used for bleaching. The hypochlorite ion that is formed when chloride gas reacts with water in the flour is a strong oxidizing agent. Chlorinated flour has exceptional cake-making properties, as its use in cake systems tends to prohibit collapse after baking [24] and results in cakes with high volumes and uniform grain and good sensory properties [25]. Bosmans et al. (2019)•• recently showed that gluten proteins lose part of their network forming capabilities as a result of chlorination. Furthermore, chlorination also influences starch and lipid functionality [24, 25]. Azodicarbonamide is another oxidizing agent that is commonly added to flour as a bleaching agent, although, as is also the case for chlorine gas, its use is prohibited in the European Union. This oxidant rapidly oxidizes free SH groups of flour proteins. It is therefore used as a dough improving agent during dough mixing (cfr. infra) [25]. 
144 Flour may also be subjected to heat treatment. Like chlorinated flour application, heat treated

145 flour use prevents collapse during baking of cake systems [26]. Although it is assumed that mainly starch properties are affected during heat treatment [27]•, it does affect gluten extensibility [28].

147 Van Steertegem et al. (2013) reported crosslinking of protein in flour particles as a result of flour heat treatment. They related this upfront polymerization to poor hydration and network formation during mixing. Nevertheless, the precise mechanisms by which heat treatment alters flour properties are still subject of debate.

\section{Dough formulation}

During dough mixing, flour particles are hydrated and sheared to such extent that they no longer exist as separate entities. As a result, gluten proteins form a continuous network. Dough mechanical behavior of course strongly depends on its water content [30]. Nowadays, the baking industry faces with the increasingly important consumer demand for salt reduction. Based on the National Diet and Food Survey in the UK, cereals and cereal products have been estimated to contribute $35 \%$ of total sodium consumption [112]. However, salt reduction may result in weaker gluten networks and impair dough handling characteristics [31]. In this context, Lynch et al. [113] reported that omission of salt leads to a significant reduction in dough and bread quality. However, reducing salt level from $1.2 \%$ to $0.3 \%$ did not significantly affect the rheological properties and bread-making performances of wheat dough. Salt likely shields charges on the gluten proteins, thus limiting electrostatic repulsion between gluten polymers and allowing them to aggregate [12,114]. Wellner et al. [114] reported an increase in the level of intermolecular $\beta$-sheets in gluten proteins isolated from flour-water doughs containing small amounts of table salt, compared to those of control flour-water dough. The presence of these structures alone may increase molecular rigidity and, as a consequence, dough strength [115]. Increasing the level of table salt from 0.2 to $1.0 \mathrm{M}$ did not induce any further changes in secondary protein structure [114]. According to McCann and Day [32], the presence of salt delays the formation of the gluten network. This has been attributed to a reduction of the

171 rate of gluten hydration. Finally, salt is thought to, to some degree, inhibit proteolytic enzymes 
172 [12]. Although table salt is typically used in wheat bread making, it is of note that different salts 173 may induce different gluten protein conformations, at least at higher concentrations. Indeed, at 174 low salt concentration (0.1 - 0.3 M), all ions have a similar effect on protein aggregation in dough 175 systems, most likely by limiting electrostatic repulsion between polymers, as described above 176 [116]. At higher salt concentrations (> $0.3 \mathrm{M})$ however, salt type and the different effect of 177 chaotropic and kosmotropic anions on water structure dictate protein aggregation [117]. Indeed, 178 at high salt concentrations, gluten protein extractability and aggregation depends on the anion 179 type and follow the lyotropic anion (i.e. 'Hofmeister') series [116]. In this context, Wellner et al. 180 [114] reported different effects of increasing concentrations of sodium bromide and sodium 181 iodide on the equilibrium between $\beta$-turn and $\beta$-sheet structures than those observed for table 182 salt. They ascribed these differences to the different chaotropic properties of the anions 183 released.

184 Yeast and, in particular, its metabolites produced during fermentation also impact the gluten 185 network. The effects on dough rheology of ethanol [33], succinic acid [34] and glycerol [35]•• 186 which are produced during fermentation, and of glutathione, which is released by yeast after cell 187 death [36]• (cfr. infra), have all been shown to be significant.

188 Although wheat gluten is the main (or only) network forming component in most traditional 189 190 wheat bread recipes, other wheat flour based dough systems may be more complex. For example, pasta dough, cookie dough, donut dough and (pre)dough for multiple types of pastry 191 products typically include proteins from other sources such as eggs and milk (powder). Some 192 basic work on co-protein network formation between gluten proteins and some common 193 (globular) food proteins was carried out by Lambrecht et al. (2017). They reported synergistic co194 protein effects (i.e. increased heat-induced polymerization of proteins mixtures in comparison with the isolated proteins) in dispersions of isolated wheat gluten with S-ovalbumin, egg white, whole egg, defatted egg yolk, bovine serum albumin, wheat albumin and wheat globulin. Soy glycinin did not partake in co-protein network formation with wheat gluten, whereas hen egg lysozyme even resulted in antagonistic co-protein effects. They concluded that the level of (accessible) free SH-groups and the surface hydrophobicity of unfolded globular proteins are the main determinants of co-protein network formation with isolated gluten during heating in water. 
201 In the context of complex food systems, co-protein network formation has been studied to some 202 extent in e.g. pound cake and noodles [for a recent review on the subject, the reader is referred 203 to Lambrecht et al. (2018)••]. Nevertheless, research on mixed protein network development 204 during bread dough mixing is limited. Egg yolk and egg white respectively increase and decrease 205 wheat dough development time, strength and stability [37]. Inclusion of sodium caseinate or 206 hydrolyzed casein in a wheat flour dough recipe results in low proof times, high bread volume 207 and crumb softness [38]. Whey protein concentrates on the other hand have been reported to 208 increase dough development time [39] and to increase proof time and decrease loaf volume [38]. 209 Soy products interfere with gluten formation, weaken dough strength and decrease its gas retention capacity [40]. According to Pérez et al. (2008), soy and wheat proteins interact through non-covalent interactions as well as through SS bond formation during dough mixing and resting.

212 The dough weakening effect can thus be ascribed to SH-SS exchange reactions and the loss of some gluten protein from the gluten network. Bonet et al. (2006) also reported that inclusion of 214 soy flour in wheat flour dough recipes significantly modifies the mixing characteristics, but concluded from capillary electrophoresis studies that interactions occurred mainly within 216 proteins from the same source. Nevertheless, the exact mechanisms by which mixed networks 217 may be formed at the bread dough level are not well documented.

218 Other typical bakery ingredients also impact gluten networks. The presence of sugar for example 219 has been associated with a reduction in bread dough consistency, increased stickiness and 220 improved extensibility. This has traditionally been linked to sugar's high affinity for water, leaving 221 less water available to hydrate gluten and starch [44]. Furthermore, sucrose containing solvents 222 are less potent gluten plasticizers than pure water [118]. According to Uedaira and Uedaira 223 (1980) [119], sucrose solutions are less favorable solvents for aliphatic and aromatic amino acids 224 than pure water. It would thus require more energy for nonpolar side chains to be exposed in a 225 sucrose solution [119]. This implies that gluten protein conformation may be different in the 226 presence of sucrose/water than in water. In bakery products with high sucrose contents, such as 227 cookies [118] and cakes, the presence of sucrose is indeed known to increase the temperature 228 necessary for protein cross-linking during baking. Shortening and other fat sources have been 
suggested to lubricate the gluten proteins and limit their water uptake during pastry making [45, 46].

\section{Energy-input}

Belton (2005) [47] subdivided dough formation in two, simultaneously occurring stages: a hydration stage and an energy input stage through deformation during dough kneading. In the second stage, depolymerization and (re)polymerization reactions take place [47, 48]. Mixing intensity and energy are critical parameters that have a large impact on final product properties. Both must be above a minimum critical level to develop the dough properly, the level varying with flour and mixer type [49]. Multiple researchers have examined the impact of mixing time and intensity on gluten protein network development $[37,49,50]$.

A typical unit operation during industrial wheat flour dough making is passing dough (sheets) through a pair of cylindrical rolls, i.e. 'dough sheeting'. The pressure exerted by the sheeting rolls transfers energy to dough, resulting in dough strengthening [51]. In the case of laminated pastry products, which undergo multiple sheeting and folding steps, this additional energy input is anticipated for by working with under-mixed dough. Dough sheeting aligns the gluten network along the final direction of sheeting [51], which results in dough 'snapback' or 'elastic recoil. Some researchers have attempted to model this dough contraction behavior [52-54].

The input of mechanical energy should not exceed an optimal level. Indeed, when wheat flour dough mixing is continued beyond the optimum, dough breakdown takes place, during which the proportion and the average molecular weight of large non-extractable polymeric protein significantly decreases [55]. According to Danno and Hoseney [120], overmixing leads to breakdown of disulfide bonds, which would explain these observations. Skerritt et al. [121] confirmed these findings, but state that the cleavage of SS bonds during overmixing is not a random process. Based on sodium dodecyl sulfate polyacrylamide gel electrophoresis and reversed phase high performance gel electrophoresis experiments, they concluded that specific HMM-GS are lost from the gluten network during dough breakdown, as are B-type LMM-GS. On the other hand, the inclusion of C-type LMM-GS, which have a higher hydrophobicity, in the 
257 gluten network increased. According to Bock and Seetharaman (2012), the Belton-model (cfr. 258 supra) implicitly assumes that during prolonged dough mixing $\beta$-sheet structures (i.e. trains) 259 develop at the expense of $\beta$-turns (i.e. loops) or, presumably, all other secondary protein 260 conformations, and that $\beta$-sheets confer less elasticity than $\beta$-turns. Eventually, at a threshold 261 ratio of $\beta$-sheet to $\beta$-turns, the dough would become resistant to further deformation and 262 prolonged mixing would result in breakdown of the gluten network. Whatever be the case, dough 263 breakdown and the mechanisms behind this phenomena during prolonged mixing are not fully 264 understood.

\subsubsection{Use of redox agents}

267 Redox agents are frequently used in the bread-making industry to optimize gluten performance 268 in different applications or for research purposes to selectively alter the gluten network and/or 269 study the resulting product properties. In general, addition of oxidizing agents (in appropriate 270 dosages) increases dough strength since they promote SS-bond formation within glutenin 271 polymers [56]. Reducing agents on the other hand, weaken wheat flour dough by reducing the 272 molecular weight of glutenin polymers through SH-SS interactions [25]. As different components 273 are characterized by different reaction rates, the impact of seemingly similar agents on dough 274 properties is not always comparable. For example, potassium bromate $\left(\mathrm{KBrO}_{3}\right)$ is a slow acting 275 oxidant mostly active during fermentation [in the absence of molecular oxygen $\left(\mathrm{O}_{2}\right)$ ] and baking 276 [57], whereas potassium iodate $\left(\mathrm{KIO}_{3}\right)$ is fast acting and mostly active during mixing [58]. 277 Furthermore, the working mechanism of certain redox agents such as ascorbic acid is more 278 complex and despite excellent research on the topic [59-61] still not completely understood. The 279 use of oxidants is more permitted in the United States but restricted in the European Union, 280 which permits only the use of ascorbic acid. In general, due to the great number and the 281 complexity of oxido-reduction reactions occurring during bread making, the effects of oxidative 282 reagents are insufficiently understood. 
284 In Table 1, an overview of some of the most commonly used redox agents in wheat flour dough making is given, along with some key references in which their mode of action is thoroughly examined, as these are outside of the scope of this article.

\subsubsection{Use of enzymes}

289 Since enzymes are (in most cases) fully denatured during baking and do not need to be labelled 290 [25], they provide a 'clean-label' alternative to chemical agents. Typically, redox enzymes 291 (oxidoreductases) in dough making are used to directly or indirectly crosslink gluten proteins 292 through various covalent bonds, i.e. for strengthening the dough system [25]. Nevertheless, 293 appropriate use of (endo)peptidases, which hydrolyze gluten too some extent during dough 294 mixing and fermentation, may also improve bread crumb textural properties [62, 63]. The effects 295 of peptidases strongly depend on the dough-making methods used, on flour quality and on the 296 presence of other functional ingredients [64]. They also serve as a useful tool to study gluten 297 protein functionality. In this context, Verbauwhede et al. (2018)•• recently examined the use of 298 aqualysin 1 from Thermus aquaticus, the hydrolyzing action of which is inhibited by wheat 299 endogenous serin peptidase inhibitors during mixing and fermentation, but no longer during baking. Multiple studies have focused on combinations of enzymes $[65,66]$. It is indeed worth noting that commercial enzyme-based dough improvers are hardly ever single enzyme preparations. Besides the main enzyme activity, a range of other enzymes can be present, either 304 deliberately added [64].

305 In Table 2, an overview of some of the most commonly used gluten-impacting enzymes in wheat 306 flour dough making is given, along with some key references. For a more extensive review on 307 enzyme use in wheat flour dough making, the reader is referred to Joye et al. (2009b) and Van 308 Oort (2010).

\subsubsection{Other additives}


311 Some emulsifiers strengthen or stabilize dough systems, presumably at least in part through

312 interaction with the gluten network [67]. Diacetyl tartaric esters of monodiglycerides and 313 ethoxylated monoglycerides both exhibit excellent dough stabilizing properties. Although their 314 exact working mechanism is unclear, they have been suggested to be able to form liquid lamellar 315 films between gluten and starch, thereby improving the film forming properties of the gluten 316 [68]. Sodium stearoyl lactylate can also strengthen dough [46] and presumably preferably 317 interacts with or binds to gliadin proteins [37].

318 For a thorough review on the role of emulsifiers and other lipids in wheat flour dough making, 319 the reader is referred to Pareyt et al. (2011).

\section{CONCLUSIONS AND PERSPECTIVES}

322 A lot of focus has been on the importance of SS bond formation during dough making. Redox 323 agents and oxidoreductase enzymes are the most commonly used tools for altering the gluten network. Although SS bonds are of major importance, the contribution of non-covalent hydrogen bond and hydrophobic interactions is less well documented. Also, in spite of the large number of excellent studies dedicated to the topic, the exact working mechanism of certain bread improving agents, such as ascorbic acid, still remains unclear and deserves more attention. All the above shows that small differences in the ingredient bill or dough making procedures may result in significantly altered gluten protein networks. In specific bakery products and industrial applications, learnings from (simplified) models, such as water-flour dough systems may thus not always (fully) apply. For research purposes, it is therefore of utmost importance to clearly specify dough formulations and mixing procedures, also when comparing results of different authors. Finally, as this review points out, the amount of available literature on gluten proteins is somewhat overwhelming. Therefore, there is a need for integrating knowledge coming from different approaches (e.g. structural features of gluten proteins as investigated through proteomics-based approaches vs. empirical measurements of dough rheology in realistic developments in the field. 


\section{Acknowledgements}

341 This work is part of the Methusalem program 'Food for the Future' at KU Leuven. J.A. Delcour is 342 W.K. Kellogg Chair of Cereal Science and Nutrition at KU Leuven. 

network formation or as an improving agent. Underlined references are review articles.

\begin{tabular}{|c|c|c|}
\hline REDOX AGENT & APPLICATION & KEY REFERENCES \\
\hline $\begin{array}{l}\text { Molecular oxygen } \\
\text { The most important oxidant in bread making. It is incorporated } \\
\text { during dough mixing. }\end{array}$ & $\begin{array}{l}\text { Flour-water dough } \\
\text { Bread dough }\end{array}$ & $\begin{array}{l}\text { Xu, } 2001[69] \\
\text { Hawthorn et al., } 1955 \text { [70] } \\
\text { Marston, } 1986[71] \\
\text { Campbell, 2003 [72] } \\
\text { Decamps et al., 2016 [73]•• }\end{array}$ \\
\hline $\begin{array}{l}\text { Potassium bromate } \\
\text { Slow acting oxidant, mainly active during fermentation and } \\
\text { baking }\end{array}$ & $\begin{array}{l}\text { Hydrated gluten } \\
\text { Bread dough }\end{array}$ & $\begin{array}{l}\text { Lagrain et al., } 2006 \\
\text { Dong and Hoseney, } 1995 \text { [15] } \\
\text { Mair et al., } 1979 \text { [74] } \\
\text { Lagrain et al., 2007 [75] } \\
\text { Joye et al., 2009b [25] } \\
\end{array}$ \\
\hline $\begin{array}{l}\text { Potassium iodate } \\
\text { lodates are strong oxidants and have a fast effect during dough } \\
\text { mixing. lodate oxidizes free thiol groups and is itself reduced to } \\
\text { iodide. }\end{array}$ & $\begin{array}{l}\text { Hydrated gluten } \\
\text { Bread dough } \\
\text { Cookie dough } \\
\text { Laminated dough }\end{array}$ & $\begin{array}{l}\text { Veraverbeke et al, } 1999 \text { [58] } \\
\text { Lagrain et al., } 2006 \\
\text { Joye et al., 2009b [25] } \\
\text { Gaines, } 1990 \text { [76] } \\
\text { Pareyt et al., } 2010 \text { [77] } \\
\text { Ooms et al., } 2017 \text { [51] }\end{array}$ \\
\hline $\begin{array}{l}\text { Asorbic acid/dehydroascorbic acid } \\
\text { Ascorbic acid is essentially a reducing agent, but in dough is } \\
\text { converted to dehydroascorbic acid in the presence of molecular } \\
\text { oxygen by endogenously present ascorbic acid oxidase. } \\
\text { Dehydroascorbic acid can reduce glutathione, hence, causing } \\
\text { dough strengthening. The exact mechanism is unclear. }\end{array}$ & Bread dough & $\begin{array}{l}\text { Elkassabany and Hoseney, } 1980 \\
\text { [78] } \\
\text { Stear, } 1990 \text { [79] } \\
\text { Nakamura et al., } 1997 \text { [80] } \\
\text { Every et al., } 1999 \text { [59] } \\
\text { Wieser, 2003 [23] } \\
\text { Grosch and Wieser, 1999 [60] } \\
\text { Joye et al., 2009b [25] }\end{array}$ \\
\hline $\begin{array}{l}\text { Azodicarbonamide } \\
\text { A fast acting oxidant that rapidly oxidizes free thiol groups and is } \\
\text { itself reduced to biurea. }\end{array}$ & $\begin{array}{l}\text { Flour-water dough } \\
\text { Bread dough }\end{array}$ & $\begin{array}{l}\text { Miller and Hoseney, } 1999[81] \\
\text { Yamada and Preston, } 1992[82] \\
\text { La et al., } 2004[83] \\
\text { Yasui et al., } 2016[84]\end{array}$ \\
\hline $\begin{array}{l}\text { Calcium peroxide/acetone peroxide } \\
\text { In presence of water peroxides releases hydrogen peroxide, } \\
\text { which is presumably the active compound and strenghtens the } \\
\text { gluten network through radical crosslinking reactions. }\end{array}$ & Bread dough & $\begin{array}{l}\text { Tieckelmann and Steele, } 1991 \text { [85] } \\
\text { Wieser, } 2003 \text { [23] } \\
\text { Takasaki et al., 2005 [86] } \\
\text { Joye et al., 2009b [25] }\end{array}$ \\
\hline $\begin{array}{l}\text { Glutathione } \\
\text { A reducing agent containing a thiol group, which can easily be } \\
\text { oxidised to protein bound glutathione. Often added in the form } \\
\text { of inactive dry yeast. }\end{array}$ & $\begin{array}{l}\text { Hydrated gluten } \\
\text { Cookie dough } \\
\text { Bread dough }\end{array}$ & $\begin{array}{l}\text { Lagrain et al., } 2006 \\
\text { Pareyt et al., } 2010 \text { [77] } \\
\text { Lagrain et al., 2007 } \\
\text { Joye et al., 2009a [87] } \\
\end{array}$ \\
\hline $\begin{array}{l}\text { L-Cysteine } \\
\text { A reducing agent. Its supplementation results in dough } \\
\text { weakening, with decreases in the elastic and viscous properties, } \\
\text { mixing time and tolerance to mixing. }\end{array}$ & $\begin{array}{l}\text { Bread dough } \\
\text { Laminated dough }\end{array}$ & $\begin{array}{l}\text { Angioloni and Dalla Rosa, } 2007 \\
\text { [88] } \\
\text { Joye et al., 2009a [87] } \\
\text { Ooms et al., 2017, 2018 [51, 89] }\end{array}$ \\
\hline $\begin{array}{l}\text { Sodium metabisulfite } \\
\text { This reducing agent is hydrolysed by water to bisulfite, which } \\
\text { reacts with protein disulfide groups by interchange, leaving a } \\
\text { thiolsulfate ester on one protein. This ester is hydrolysed by } \\
\text { water, yielding a free thiol group on the protein and a sulfate ion. }\end{array}$ & Cookie dough & $\begin{array}{l}\text { Oliver et al., } 1995 \text { [90] } \\
\text { Wieser, } 2003[23] \\
\text { Pendersen et al., } 2005[91]\end{array}$ \\
\hline
\end{tabular}

\section{5}


Table 2: An overview of chemical redox agents used in dough systems either as tool for studying gluten 348 network formation or as improving agent. Underlined references are review articles.

\begin{tabular}{|c|c|c|}
\hline ENZYME & APPLICATION & KEY REFERENCES \\
\hline $\begin{array}{l}\text { Glucose oxidase [EC 1.1.3.4] } \\
\text { Specifically catalyzes the oxidation of } C 1 \text { of } 8 \text {-D-glucose, } \\
\text { producing hydrogen peroxide } \mathrm{H}_{2} \mathrm{O}_{2} \text { and D-glucono- } \delta \text {-lactone. } \\
\text { Hydrogen peroxide may indirectly oxidise the gluten thiol } \\
\text { groups crosslinking the gluten proteins }\end{array}$ & $\begin{array}{l}\text { Bread dough } \\
\text { Laminated dough }\end{array}$ & $\begin{array}{l}\text { Bonet et al., } 2006 \text { [92] } \\
\text { Hanft et al., } 2006 \text { [93] } \\
\text { Bankar et al., 2009 [94] } \\
\text { Steffolani et al., } 2010 \text { [95] } \\
\text { Decamps et al, 2012a [96] } \\
\text { Rasiah et al., } 2005 \text { [97] }\end{array}$ \\
\hline $\begin{array}{l}\text { Hexose oxidase [EC 1.1.3.5] } \\
\text { Catalyzes the oxidation of several mono- and oligosaccharides } \\
\text { to lactones and hydrogen peroxide, which is thought to be the } \\
\text { active compound inducing the formation of disulfide bonds. }\end{array}$ & Bread dough & $\begin{array}{l}\text { Poulsen and Hostrup, } 1998 \text { [98] } \\
\text { Hanft and Koehler, } 2005 \text { [99] }\end{array}$ \\
\hline $\begin{array}{l}\text { Sulfhydryl oxidase [1.8.3.2] } \\
\text { Catalyzes the formation of disulfide bonds from a variety of } \\
\text { thiol groups. However, its affinity for thiol groups in protein } \\
\text { chains seems limited. }\end{array}$ & Bread dough & $\begin{array}{l}\text { Kaufman et al., } 1987[102] \\
\text { Van Oort, } 2010[64] \\
\text { Faccio et al., } 2012[103]\end{array}$ \\
\hline $\begin{array}{l}\text { Transglutaminase [EC } \mathbf{2 . 3 . 2 . 1 3 ]} \\
\text { Introduces covalent isopeptide bonds through catalyzation of } \\
\text { acyl-transfer reactions. }\end{array}$ & $\begin{array}{l}\text { Bread dough } \\
\text { Laminated dough }\end{array}$ & $\begin{array}{l}\text { Gerrard et al., } 1998 \text { [104] } \\
\text { Bauer et al., } 2003 \text { [105] } \\
\text { Caballero, } 2007 \text { [65] } \\
\text { Steffolani et al., } 2010 \text { [95] } \\
\text { Kieliszek and Misiewicz, 2014 [111]• } \\
\text { Gerrard et al., } 2000 \text { [106] } \\
\text { Hozova et al., } 2002 \text { [107] } \\
\text { Ooms et al., } 2016 \text { [108] }\end{array}$ \\
\hline $\begin{array}{l}\text { Peptidases } \\
\text { Hydrolyze peptide bonds and, if active during mixing, lower } \\
\text { dough strength. Enzymes with affinities for different amino- } \\
\text { acid sequences and with different optimal working conditions } \\
\text { have been tested. }\end{array}$ & Bread dough & $\begin{array}{l}\text { Martínez-Anaya, } 1996 \text { [109] } \\
\text { Harada et al., } 2000[110] \\
\text { Van Oort, } 2010[64]\end{array}$ \\
\hline
\end{tabular}




\section{REFERENCES}

352 1. Delcour, J.A., Joye, I.J., Pareyt, B., Wilderjans, E., Brijs, K., and Lagrain, B., Wheat 353 gluten functionality as a quality determinant in cereal-based food products. Annual Review of 354 Food Science and Technology, 2012. 3: p. 469-492.

3552 2. -Bock, J. and Seetharaman, K., Unfolding gluten: an overview of research on gluten. 356 Cereal Foods World, 2012. 57(5): p. 209-214.

357 A brief review article outlining research focused on the gluten network and some 358 perspectives in this field.

3. Lagrain, B., Brijs, K., and Delcour, J.A., Reaction Kinetics of Gliadin-Glutenin CrossLinking in Model Systems and in Bread Making. Journal of Agricultural and Food Chemistry, 2008. 56(22): p. 10660-10666.

4. Wieser, H., Chemistry of gluten proteins. Food Microbiology, 2007. 24(2): p. 115-119. 5. Woychik, J., Boundy, J.A., and Dimler, R., Wheat gluten proteins, amino acid composition of proteins in wheat gluten. Journal of Agricultural and Food Chemistry, 1961. 9(4): p. 307-310.

6. Rombouts, I., Lamberts, L., Celus, I., Lagrain, B., Brijs, K., and Delcour, J.A., Wheat gluten amino acid composition analysis by high-performance anion-exchange chromatography with integrated pulsed amperometric detection. Journal of Chromatography A, 2009. 1216(29): p. 5557-5562.

7. Mamone, G., Ferranti, P., Chianese, L., Scafuri, L., and Addeo, F., Qualitative and quantitative analysis of wheat gluten proteins by liquid chromatography and electrospray mass spectrometry. Rapid Communications in Mass Spectrometry, 2000. 14(10): p. 897-904. analytical approach for the characterization of glutenin subunits in durum wheat. Journal of Mass Spectrometry, 2009. 44(12): p. 1709-1723. 9. Anjum, F.M., Khan, M.R., Din, A., Saeed, M., Pasha, I., and Arshad, M.U., Wheat gluten: high molecular weight glutenin subunits-structure, genetics, and relation to dough elasticity. Journal of Food Science, 2007. 72(3): p. R56-R63. genetic, and molecular characterization of wheat glutenin and its component subunits. Cereal Chemistry, 2001. 78(6): p. 635-646. Journal of Cereal Science, 1996. 23(1): p. 1-17. 
12. Delcour, J.A. and Hoseney, R.C., Principles of Cereal Science and Technology. 2010, St. Paul, MN, USA: AACC International.

13. Veraverbeke, W.S. and Delcour, J.A., Wheat protein composition and properties of wheat glutenin in relation to breadmaking functionality. Critical Reviews in Food Science and Nutrition, 2002. 42(3): p. 179-208.

14. Schofield, J., Bottomley, R., Timms, M., and Booth, M., The effect of heat on wheat gluten and the involvement of sulphydryl-disulphide interchange reactions. Journal of Cereal Science, 1983. 1(4): p. 241-253.

15. Dong, W. and Hoseney, R., Effects of certain breadmaking oxidants and reducing agents on dough rheological properties. Cereal chemistry, 1995. 72(1): p. 58-63.

16. Morel, M.-H., Redl, A., and Guilbert, S., Mechanism of heat and shear mediated aggregation of wheat gluten protein upon mixing. Biomacromolecules, 2002. 3(3): p. 488-497. 17. Peña, E., Bernardo, A., Soler, C., and Jouve, N., Do tyrosine crosslinks contribute to the formation of the gluten network in common wheat (Triticum aestivum L.) dough? Journal of Cereal Science, 2006. 44(2): p. 144-153.

18. Tilley, K.A., Benjamin, R.E., Bagorogoza, K.E., Okot-Kotber, B.M., Prakash, O., and Kwen, H., Tyrosine cross-links: molecular basis of gluten structure and function. Journal of Agricultural and Food Chemistry, 2001. 49(5): p. 2627-2632.

19. Weegels, P., De Groot, A., Verhoek, J., and Hamer, R., Effects on gluten of heating at different moisture contents. II. Changes in physico-chemical properties and secondary structure. Journal of Cereal Science, 1994. 19(1): p. 39-47.

20. Fu, B., Sapirstein, H., and Bushuk, W., Salt-induced disaggregation/solubilization of gliadin and glutenin proteins in water. Journal of Cereal Science, 1996. 24(3): p. 241-246.

21. Saiz, A., Manrique, G., and Fritz, R., Determination of benzoyl peroxide and benzoic acid levels by HPLC during wheat flour bleaching process. Journal of Agricultural and Food Chemistry, 2001. 49(1): p. 98-102.

22. Fennema, O.R. Food additives. In: Food Chemistry, 2nd edition, ed. O.R. Fennema. 1985, Marcel Dekker: New York. 629-687.

23. Wieser, H. The use of redox agents in breadmaking. In: Breadmaking: Improving quality, ed. S.P. Cauvain. 2003, Woodhead Publishing Limited: Cambrigde, UK. 424-446.

24. ••Bosmans, G.M., Peene, L.J., Van Haesendonck, I., Brijs, K., and Delcour, J.A., Impact of chlorine treatment on properties of wheat flour and its components in the presence of sucrose. Food Chemistry, 2019. 274: p. 434-443. 
Excellent research article re-examining the effect of flour chlorine treatment with modern techniques such as ${ }^{1} \mathrm{H}$ NMR.

25. Joye, I.J., Lagrain, B., and Delcour, J.A., Use of chemical redox agents and exogenous enzymes to modify the protein network during breadmaking-A review. Journal of Cereal Science, 2009b. 50(1): p. 11-21.

26. Chesterton, A., Wilson, D.I., Sadd, P., and Moggridge, G.D., A novel laboratory scale method for studying heat treatment of cake flour. Journal of Food Engineering, 2015. 144: p. $36-44$.

27. •Keppler, S., Bakalis, S., Leadley, C., Sahi, S., and Fryer, P., Evaluation of dry heat treatment of soft wheat flour for the production of high ratio cakes. Food Research International, 2018. 107: p. 360-370.

Solid research article examining the effect of heat treatment on a laboratory scale on gluten protein functionality and its impact on high ratio cake properties.

28. Neill, G., Al-Muhtaseb, A.a.H., and Magee, T.R.A., Optimisation of time/temperature treatment, for heat treated soft wheat flour. Journal of Food Engineering, 2012. 113(3): p. 422426.

29. Van Steertegem, B., Pareyt, B., Slade, L., Levine, H., Brijs, K., and Delcour, J.A., Impact of heat treatment on wheat flour solvent retention capacity (SRC) profiles. Cereal Chemistry, 2013.90(6): p. 608-610.

30. Belton, P., New approaches to study the molecular basis of the mechanical properties of gluten. Journal of Cereal Science, 2005. 41(2): p. 203-211.

31. Belz, M.C.E., Ryan, L.A.M., and Arendt, E.K., The Impact of Salt Reduction in Bread: A Review. Critical reviews in food science and nutrition, 2012. 52(6): p. 514-524.

32. McCann, T.H. and Day, L., Effect of sodium chloride on gluten network formation, dough microstructure and rheology in relation to breadmaking. Journal of Cereal Science, 2013. 57(3): p. 444-452.

33. Jayaram, V.B., Rezaei, M.N., Cuyvers, S., Verstrepen, K.J., Delcour, J.A., and Courtin, C.M., Ethanol at levels produced by Saccharomyces cerevisiae during wheat dough fermentation has a strong impact on dough properties. Journal of Agricultural and Food Chemistry, 2014a. 62(38): p. 9326-9335.

34. Jayaram, V.B., Cuyvers, S., Verstrepen, K.J., Delcour, J.A., and Courtin, C.M., Succinic acid in levels produced by yeast (Saccharomyces cerevisiae) during fermentation strongly impacts wheat bread dough properties. Food Chemistry, 2014b. 151: p. 421-428. 
450

451

452

453

454

455

456

457

458

459

460

461

462

463

464

465

466

467

468

469

470

471

472

473

474

475

476

477

478

479

480

481

482

483

35. ••Meerts, M., Cervera, A.R., Struyf, N., Cardinaels, R., Courtin, C.M., and Moldenaers, P., The effects of yeast metabolites on the rheological behaviour of the dough matrix in fermented wheat flour dough. Journal of Cereal Science, 2018.

Solid research article exploring the rheological impact of yeast's main metabolites, using (novel) fundamental rheological techniques.

36. -Verheyen, C., Albrecht, A., Herrmann, J., Strobl, M., Jekle, M., and Becker, T., The contribution of glutathione to the destabilizing effect of yeast on wheat dough. Food Chemistry, 2015. 173: p. 243-249.

Excellent research article adressing the large variety in glutathione content of different (fresh and dried) commercial yeast samples and, as a consequence, their different impact during bread making.

37. Van Steertegem, B., Pareyt, B., Brijs, K., and Delcour, J.A., Impact of mixing time and sodium stearoyl lactylate on gluten polymerization during baking of wheat flour dough. Food Chemistry, 2013. 141(4): p. 4179-4185.

38. Kenny, S., Wehrle, K., Stanton, C., and Arendt, E.K., Incorporation of dairy ingredients into wheat bread: effects on dough rheology and bread quality. European Food Research and Technology, 2000. 210(6): p. 391-396.

39. Ammar, A.S., Salem, S.A., and Badr, F.H., Rheological properties of wheat flour dough as affected by addition of whey and soy proteins. Pakistan Journal of Nutrition, 2011. 10(4): p. 302-306.

40. Ribotta, P.D., Arnulphi, S.A., León, A.E., and Añón, M.C., Effect of soybean addition on the rheological properties and breadmaking quality of wheat flour. Journal of the Science of Food and Agriculture, 2005. 85(11): p. 1889-1896.

41. Perez, G.T., Ribotta, P.D., Steffolani, M.E., and León, A.E., Effect of soybean proteins on gluten depolymerization during mixing and resting. Journal of the Science of Food and Agriculture, 2008. 88(3): p. 455-463.

42. Bonet, A., Blaszczak, W., and Rosell, C.M., Formation of homopolymers and heteropolymers between wheat flour and several protein sources by transglutaminasecatalyzed cross-linking. Cereal Chemistry, 2006. 83(6): p. 655-662.

43. ••Lambrecht, M.A., Deleu, L.J., Rombouts, I., and Delcour, J.A., Heat-induced network formation between proteins of different sources in model systems, wheat-based noodles and pound cakes. Food Hydrocolloids, 2018. 79: p. 352-370.

Review discussing the importance of heat-induced crosslinks between proteins of different sources on product quality. 
44. Salvador, A., Sanz, T., and Fiszman, S.M., Dynamic rheological characteristics of wheat flour-water doughs. Effect of adding $\mathrm{NaCl}$, sucrose and yeast. Food Hydrocolloids, 2006. 20(6): p. 780-786.

45. Cauvain, S.P. and Young, L.S., Baked Products Science, Technology and Practice. 2006, Oxford, UK: Blackwell Publishing Ltd.

46. Pareyt, B., Finnie, S.M., Putseys, J.A., and Delcour, J.A., Lipids in bread making: Sources, interactions, and impact on bread quality. Journal of Cereal Science, 2011. 54(3): p. 266-279.

47. Belton, P.S., Mini Review: On the Elasticity of Wheat Gluten. Journal of Cereal Science, 1999. 29(2): p. 103-107.

48. Weegels, P.L., Hamer, R.J., and Schofield, J.D., Depolymerisation and Repolymerisation of Wheat Glutenin During Dough Processing. II. Changes in Composition. Journal of Cereal Science, 1997. 25(2): p. 155-163.

49. Angioloni, A. and Dalla Rosa, M., Dough thermo-mechanical properties: influence of sodium chloride, mixing time and equipment. Journal of Cereal Science, 2005. 41(3): p. 327331.

50. Rouillé, J., Le Bail, A., and Courcoux, P., Influence of formulation and mixing conditions on breadmaking qualities of French frozen dough. Journal of Food Engineering, 2000. 43(4): p. 197-203.

51. Ooms, N., Pareyt, B., Jansens, K.J.A., Reyniers, S., Brijs, K., and Delcour, J.A., The impact of redox agents on further dough development, relaxation and elastic recoil during lamination and fermentation of multi-layered pastry dough. Journal of Cereal Science, 2017. 75: p. 84-91.

52. Engmann, J., Peck, M., and Wilson, D., An experimental and theoretical investigation of bread dough sheeting. Food and Bioproducts Processing, 2005. 83(3): p. 175-184.

53. Qi, F., Dai, S.-C., Newberry, M.P., Love, R.J., and Tanner, R.I., A simple approach to predicting dough sheeting thickness. Journal of Cereal Science, 2008. 47(3): p. 489-495.

54. Xiao, W., Charalambides, M.N., and Williams, J.G., Sheeting of wheat flour dough. International Journal of Food Science \& Technology, 2007. 42(6): p. 699-707.

55. Kuktaite, R., Larsson, H. and Johansson, E. Variation in protein composition of wheat flour and its relationship to dough mixing behaviour. Journal of Cereal Science, 2004. 40(1), p.31-39. 
56. Lagrain, B., Brijs, K., and Delcour, J.A., Impact of redox agents on the physicochemistry of wheat gluten proteins during hydrothermal treatment. Journal of Cereal Science, 2006. 44(1): p. 49-53.

57. Cauvain, S.P., Technology of Bread Making. Third Edition. 2015, Witney, UK.: Springer.

58. Veraverbeke, W.S., Courtin, C.M., Verbruggen, I.M., and Delcour, J.A., Factors Governing Levels and Composition of the Sodium Dodecyl Sulphate-Unextractable Glutenin Polymers During Straight Dough Breadmaking. Journal of Cereal Science, 1999. 29(2): p. 129138.

59. Every, D., Simmons, L., Sutton, K., and Ross, M., Studies on the mechanism of the ascorbic acid improver effect on bread using flour fractionation and reconstitution methods. Journal of Cereal Science, 1999. 30(2): p. 147-158.

60. Grosch, W. and Wieser, H., Redox reactions in wheat dough as affected by ascorbic acid. Journal of Cereal Science, 1999. 29(1): p. 1-16.

61. Koehler, P., Concentrations of low and high molecular weight thiols in wheat dough as affected by different concentrations of ascorbic acid. Journal of Agricultural and Food Chemistry, 2003. 51(17): p. 4948-4953.

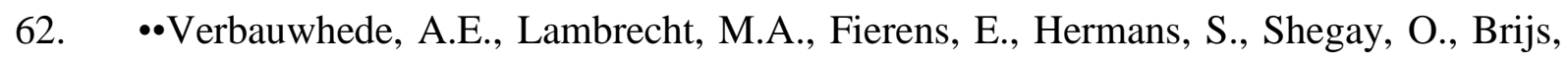
K., and Delcour, J.A., Thermo-reversible inhibition makes aqualysin 1 from Thermus aquaticus a potent tool for studying the contribution of the wheat gluten network to the crumb texture of fresh bread. Food Chemistry, 2018. 264: p. 118-125.

\section{Research article showing the limited impact of gluten network alterations through use of} a peptidase during baking on bread crumb texture.

63. Indrani, D., Prabhasankar, P., Rajiv, J., and Rao, G.V., Scanning electron microscopy, rheological characteristics, and bread-baking performance of wheat flour dough as affected by enzymes. Journal of Food Science, 2003. 68(9): p. 2804-2809.

64. Van Oort, M. Enzymes in bread making. In: Enzymes in food technology. Second edition, ed. R.J. Whitehurst and M. Van Oort. 2010, Blackwell Publishing Ltd.: West Sussex, United Kingdom.

65. Caballero, P.A., Gómez, M., and Rosell, C.M., Improvement of dough rheology, bread quality and bread shelf-life by enzymes combination. Journal of Food Engineering, 2007. 81(1): p. 42-53. 
548 66. Yang, T., Bai, Y., Wu, F., Yang, N., Zhang, Y., Bashari, M., Jin, Z., and Xu, X., 549 Combined effects of glucose oxidase, papain and xylanase on browning inhibition and 550 characteristics of fresh whole wheat dough. Journal of Cereal Science, 2014. 60(1): p. 249-254.

551 67. Goesaert, H., Brijs, K., Veraverbeke, W., Courtin, C., Gebruers, K., and Delcour, J., 552 Wheat flour constituents: how they impact bread quality, and how to impact their functionality. 553 Trends in Food Science \& Technology, 2005. 16(1): p. 12-30.

554 68. Stampfli, L. and Nersten, B., Emulsifiers in bread making. Food Chemistry, 1995. 555 52(4): p. 353-360.

556 69. Xu, F., Adsorption of oxygen gas by hydrated wheat flour. LWT-Food Science and 557 Technology, 2001. 34(2): p. 66-70.

558 70. Hawthorn, J. and Todd, J., Some effects of oxygen on the mixing of bread doughs. 559 Journal of the Science of Food and Agriculture, 1955. 6(9): p. 501-511.

560 71. Marston, P., Dough development for breadmaking under controlled atmospheres. 561 Journal of Cereal Science, 1986. 4(4): p. 335-344.

562 72. Campbell, G.M. Bread aeration. In: Bread Making: Improving Quality, ed. S.P. 563 Cauvain. 2003, Woodhead Publishing Ltd: Cambridge, UK.

564 73. ••Decamps, K., Joye, I.J., De Vos, D.E., Courtin, C.M., and Delcour, J.A., Molecular 565 oxygen and reactive oxygen species in bread-making processes: scarce, but nevertheless 566 important. Critical Reviews in Food Science and Nutrition, 2016. 56(5): p. 722-736. Thorough review article on the importance of molecular oxygen and other reactive oxygen species as oxidizing agents during bread making.

569 74. Mair, G. and Grosch, W., Changes in glutathione content (reduced and oxidised form) 570 and the effect of ascorbic acid and potassium bromate on glutathione oxidation during dough mixing. Journal of the Science of Food and Agriculture, 1979. 30(9): p. 914-920. 75. Lagrain, B., Thewissen, B.G., Brijs, K., and Delcour, J.A., Impact of redox agents on the extractability of gluten proteins during bread making. Journal of Agricultural and Food 574 Chemistry, 2007. 55(13): p. 5320-5325.

575 76. Gaines, C.S., Influence of chemical and physical modification of soft wheat protein on 576 sugar-snap cookie dough consistency, cookie size, and hardness. Cereal Chemistry, 1990. 577 67(1): p. 73-77.

578 77. Pareyt, B., Van Steertegem, B., Brijs, K., Lagrain, B., and Delcour, J.A., The impact of 579 redox agents on sugar-snap cookie making. Journal of Cereal Science, 2010. 52(2): p. 192-199. 580 78. Elkassabany, M. and Hoseney, R., Ascorbic acid as an oxidant in wheat flour dough. II. 581 Rheological effects. Cereal Chemistry, 1980. 57(2): p. 88-91. 
582

583

584

585

586

587

588

589

590

591

592

593

594

595

596

597

598

599

600

601

602

603

604

605

606

607

608

609

610

611

612

613

614

615

79. Stear, C.A., Handbook of Breadmaking Technology. 1990, Essex, UK: Elsevier science publishers Ltd.

80. Nakamura, M. and Kurata, T., Effect of L-ascorbic acid on the rheological properties of wheat flour-water dough. Cereal Chemistry, 1997. 74(5): p. 647-650.

81. Miller, K. and Hoseney, R., Effect of oxidation on the dynamic rheological properties of wheat flour-water doughs. Cereal chemistry, 1999. 76(1): p. 100-104.

82. Yamada, Y. and Preston, K., Effects of individual oxidants on oven rise and bread properties of Canadian short process bread. Journal of Cereal Science, 1992. 15(3): p. 237251.

83. La, I.-J., Lee, M.-C., Park, H.-D., and Kim, K.-P., Effects of azodicarbonamide on the rheology of wheat flour dough and the quality characteristics of bread. Journal of the Korean Society of Food Science and Nutrition, 2004. 33(9): p. 1566-1572.

84. Yasui, A., Oishi, M., Hayafuji, C., Kobayashi, C., Shindo, T., Ozawa, H., and Nakazato, M., Analysis of Azodicarbonamide in Wheat Flour and Prepared Flour Mixes. Shokuhin eiseigaku zasshi. Journal of the Food Hygienic Society of Japan, 2016. 57(5): p. 133-138.

85. Tieckelmann, R. and Steele, R., Higher-assay grade of calcium peroxide improves properties of dough. Food Technology, 1991. 45: p. 106-112.

86. Takasaki, S., Kato, Y., Murata, M., Homma, S., and Kawakishi, S., Effects of peroxidase and hydrogen peroxide on the dityrosine formation and the mixing characteristics of wheatflour dough. Bioscience, Biotechnology, and Biochemistry, 2005. 69(9): p. 1686-1692.

87. Joye, I.J., Lagrain, B., and Delcour, J.A., Endogenous redox agents and enzymes that affect protein network formation during breadmaking-A review. Journal of Cereal Science, 2009a. 50(1): p. 1-10.

88. Angioloni, A. and Dalla Rosa, M., Effects of cysteine and mixing conditions on white/whole dough rheological properties. Journal of food engineering, 2007. 80(1): p. 18-23. 89. Ooms, N., Jansens, K.J.A., Pareyt, B., Reyniers, S., Brijs, K., and Delcour, J.A., The impact of disulfide bond dynamics in wheat gluten protein on the development of fermented pastry crumb. Food Chemistry, 2018. 242: p. 68-74.

90. Oliver, G., Thacker, D., and Wheeler, R.J., Semi-sweet biscuits: 1. The influence of sodium metabisulphite on dough rheology and baking performance. Journal of the Science of Food and Agriculture, 1995. 69(2): p. 141-150.

91. Pedersen, L., Kaack, K., Bergsøe, M.N., and Adler-Nissen, J., Effects of chemical and enzymatic modification on dough rheology and biscuit characteristics. Journal of Food Science, 2005. 70(2): p. E152-E158. 
92. Bonet, A., Rosell, C.M., Caballero, P.A., Gómez, M., Pérez-Munuera, I., and Lluch, M.A., Glucose oxidase effect on dough rheology and bread quality: a study from macroscopic to molecular level. Food Chemistry, 2006. 99(2): p. 408-415.

93. Hanft, F. and Koehler, P., Studies on the effect of glucose oxidase in bread making. Journal of the Science of Food and Agriculture, 2006. 86(11): p. 1699-1704.

94. Bankar, S.B., Bule, M.V., Singhal, R.S., and Ananthanarayan, L., Glucose oxidase-an overview. Biotechnology Advances, 2009. 27(4): p. 489-501.

95. Steffolani, M.E., Ribotta, P.D., Pérez, G.T., and León, A.E., Effect of glucose oxidase, transglutaminase, and pentosanase on wheat proteins: Relationship with dough properties and bread-making quality. Journal of Cereal Science, 2010. 51(3): p. 366-373.

96. Decamps, K., Joye, I.J., Haltrich, D., Nicolas, J., Courtin, C.M., and Delcour, J.A., Biochemical characteristics of Trametes multicolor pyranose oxidase and Aspergillus niger glucose oxidase and implications for their functionality in wheat flour dough. Food Chemistry, 2012a. 131(4): p. 1485-1492.

97. Rasiah, I., Sutton, K., Low, F., Lin, H.-M., and Gerrard, J., Crosslinking of wheat dough proteins by glucose oxidase and the resulting effects on bread and croissants. Food Chemistry, 2005. 89(3): p. 325-332.

98. Poulsen, C. and Hostrup, P.B., Purification and characterization of a hexose oxidase with excellent strengthening effects in bread. Cereal Chemistry, 1998. 75(1): p. 51-57.

99. Hanft, F. and Koehler, P., Quantitation of dityrosine in wheat flour and dough by liquid chromatography - tandem mass spectrometry. Journal of Agricultural and Food Chemistry, 2005. 53(7): p. 2418-2423.

100. Decamps, K., Joye, I.J., Courtin, C.M., and Delcour, J.A., Glucose and pyranose oxidase improve bread dough stability. Journal of Cereal Science, 2012. 55(3): p. 380-384.

101. Decamps, K., Joye, I.J., Rakotozafy, L., Nicolas, J., Courtin, C.M., and Delcour, J.A., The bread dough stability improving effect of pyranose oxidase from Trametes multicolor and glucose oxidase from Aspergillus niger: unraveling the molecular mechanism. Journal of Agricultural and Food Chemistry, 2013. 61(32): p. 7848-7854.

102. Kaufman, S. and Fennema, O., Evaluation of sulfhydryl oxidase as a strengthening agent for wheat flour dough. Cereal Chemistry, 1987. 64(3): p. 172-176.

103. Faccio, G., Flander, L., Buchert, J., Saloheimo, M., and Nordlund, E., Sulfhydryl oxidase enhances the effects of ascorbic acid in wheat dough. Journal of Cereal Science, 2012. 55(1): p. 37-43. 
649

650

651

652

653

654

655

656

657

658

659

660

661

662

663

664

665

666

667

668

669

670

671

672

673

674

675

676

677

678

679

680

681

104. Gerrard, J., Fayle, S., Wilson, A., Newberry, M., Ross, M., and Kavale, S., Dough properties and crumb strength of white pan bread as affected by microbial transglutaminase. Journal of Food Science, 1998. 63(3): p. 472-475.

105. Bauer, N., Koehler, P., Wieser, H., and Schieberle, P., Studies on effects of microbial transglutaminase on gluten proteins of wheat. II. Rheological properties. Cereal Chemistry, 2003. 80(6): p. 787-790.

106. Gerrard, J., Newberry, M., Ross, M., Wilson, A., Fayle, S., and Kavale, S., Pastry lift and croissant volume as affected by microbial transglutaminase. Journal of Food Science, 2000. 65(2): p. 312-314.

107. Hozova, B., Jancovicova, J., Dodok, L., Buchtova, V., and Staruch, L., Use of transglutaminase for improvement of quality of pastry produced by frozen-dough technology.

Czech Journal of Food Sciences, 2002. 20(6): p. 215-222.

108. Ooms, N., Pareyt, B., Brijs, K., and Delcour, J.A., Ingredient functionality in multilayered dough-margarine systems and the resultant pastry products: a review. Critical Reviews in Food Science \& Nutrition, 2016. 56(13): p. 2101-2114.

109. Martínez-Anaya, M.A., Enzymes and bread flavor. Journal of Agricultural and Food Chemistry, 1996. 44(9): p. 2469-2480.

110. Harada, O., Lysenko, E., and Preston, K., Effects of commercial hydrolytic enzyme additives on Canadian short process bread properties and processing characteristics. Cereal Chemistry, 2000. 77(1): p. 70-76.

111. $\cdot$ Kieliszek, M. and Misiewicz, A. Microbial transglutaminase and its application in the food industry. A review. Folia Microbiologica, 2014. 59(3), p.241-250.

Excellent review article on the many uses of transglutaminase in the food industry, also focussing on its use in bakery applications.

112. EFSA. Opinion of the scientific panel on dietetic products, nutrition and allergies on a request from the commission related to the tolerable upper intake level of sodium. The EFSA Journal, 2005. 209, p.1-26.

113. Lynch, E.J., Dal Bello, F., Sheehan, E.M., Cashman, K.D. and Arendt, E.K. Fundamental studies on the reduction of salt on dough and bread characteristics. Food Research International, 2009. 42(7), p.885-891.

114. Wellner, N., Bianchini, D., Mills, E.C. and Belton, P.S. Effect of selected Hofmeister anions on the secondary structure and dynamics of wheat prolamins in gluten. Cereal Chemistry, 2003. 80(5), p.596-600. 
682

683

684

685

686

687

688

689

690

691

692

693

694

695

696

697

698

699

700

701

702

703

704

705

706

707

708

709

115. Rombouts, I., Jansens, K.J., Lagrain, B., Delcour, J.A. and Zhu, K.X. The impact of salt and alkali on gluten polymerization and quality of fresh wheat noodles. Journal of Cereal Science, 2014. 60(3), p.507-513.

116. He, H., Roach, R.R. and Hoseney, R.C. Effect of nonchaotropic salts on flour breadmaking properties. Cereal Chemistry, 1992. 69(4), p.366-371.

117. Melnyk, J.P., Dreisoerner, J., Bonomi, F., Marcone, M.F. and Seetharaman, K. Effect of the Hofmeister series on gluten aggregation measured using a high shear-based technique. Food Research International, 2011. 44(4), p.893-896.

118. Pareyt, B., Brijs, K. and Delcour, J.A. Sugar-snap cookie dough setting: the impact of sucrose on gluten functionality. Journal of Agricultural and Food Chemistry, 2009. 57(17), p.7814-7818.

119. Uedaira, H. and Uedaira, H. The effect of sugars on the thermal denaturation of lysozyme. Bulletin of the Chemical Society of Japan, 1980. 53(9), p.2451-2455.

120. Danno, G., and R. C. Hoseney. Effects of dough mixing and rheologically active compounds on relative viscosity of wheat proteins. Cereal Chemistry, 1982. 59(3), p.196-198.

121. Skerritt, J.H., Hac, L., Lindsay, M.P. and Bekes, F. Depolymerization of the glutenin macropolymer during mixing: II. Differences in retention of specific glutenin subunits. Cereal Chemistry, 1999. 76(3), p.402-409.

122. Wrigley, C.W., Békés, F. and Bushuk, W. Gluten: A balance of gliadin and glutenin. Gliadin and glutenin. The unique balance of wheat quality. 2006. AACC International Press, St Paul, p.3-32.

123. Sapirstein, H.D. and Fu, B.X. Evidence for varying interaction of gliadin and glutenin proteins as an explanation for differences in dough strength of different wheats. In: Wheat gluten. Proceedings of the 7th International Workshop Gluten. 2000. Royal Society of Chemistry, Bristol, UK. p. 425-429.

124. Ortolan, F. and Steel, C.J. Protein characteristics that affect the quality of vital wheat gluten to be used in baking: A review. Comprehensive Reviews in Food Science and Food Safety, 2017. 16(3), p.369-381. 
710125 . D'Ovidio, R. and Masci, S. The low-molecular-weight glutenin subunits of wheat gluten.

711 Journal of Cereal Science, 2004. 39(3), p.321-339.

712 126. Li, W., Dobraszczyk, B.J., Dias, A. and Gil, A.M. Polymer conformation structure of 713 wheat proteins and gluten subfractions revealed by ATR-FTIR. Cereal Chemistry, 2006. 83(4), 714 p.407-410.

715 127. Lambrecht, M.A., Rombouts, I., De Ketelaere, B. and Delcour, J.A. Prediction of heat716 induced polymerization of different globular food proteins in mixtures with wheat gluten. Food 717 Chemistry, 2017. 221, p.1158-1167. 